\title{
TRANSLATING JIŘÍ LEVÝ'S ART OF TRANSLATION FOR AN INTERNATIONAL READERSHIP \\ TRADUZINDO THE ART OF TRANSLATION DE JIŘÍ LEVÝ PARA UM PÚBLICO INTERNACIONAL ${ }^{1}$
}

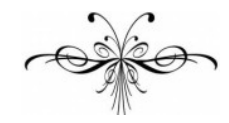 \\ ZUZANA JETTMAROVÁ \\ Gustavo AlthofF, Gustavo SARTIN (TRADUTORES)
}

\section{Introduction}

The ongoing project of translating Levý's seminal book into English was launched almost two years ago and there had been several reasons for conceiving it. The first and prime reason was making the book accessible to an international readership in today's lingua franca: here Levý's accessibility has so far been confined to his English articles, especially his Translation as a Decision Process

\section{Introdução}

O corrente projeto de tradução do seminal livro de Levý ao inglês foi iniciado há quase dois $\operatorname{anos}^{2}$, e havia muitas razões para concebê-lo. A primeira e mais importante foi tornar o livro acessível a um público internacional na lingua franca ${ }^{3}$ dos dias atuais: até o momento, o acesso a Levý tem estado limitado a seus artigos em inglês, especialmente Translation as a Decision Process (1967) e Will

\footnotetext{
${ }^{1}$ A obra Uměni překladu, de Jiří Levý, foi traduzida ao inglês por Patrick Corness, sob a editoria de Zuzana Jettmarová, com o título "The Art of Translation". Foi publicada em 2011 após a publicação original deste artigo no mesmo ano. O projeto de tradução da obra se enquadrou no arranjo institucional de pesquisas da Universidade Carolina de Praga [Univerzita Karlova v Praze] (MSM 0021620825). Este artigo representa a perspectiva da editora.

${ }^{2}$ N.T.: Este artigo foi originalmente publicado em novembro de 2011 como parte da obra "Posibilidades y límites de la comunicación intercultural", organizada por Jana Králová, também professora da Universidade Carolina de Praga.

${ }^{3}$ Existem outros projetos paralelos a este: o de Jana Králová, em Praga, de tradução da obra ao espanhol; e o de Filipe Neckel, que traduziu a primeira metade da obra ao português como parte de sua dissertação de mestrado, intitulada "Die literarische Übersetzung: apresentação da obra de Jiř́ Levý acompanhada de uma tradução comentada", defendida em julho de 2011 (PGET-UFSC). Ao passo que Venuti removeu o artigo de Levý Translation as a Decision Process da segunda edição de seu Reader (2004), Bruno Osimo, na Itália, supervisionou a tradução desse texto por um seu aluno de doutorado (2008).
} 
(1967) and Will Translation Theory be of Use to Translators? (1965). The German translation of Levý's Art of Translation as Die literarische Übersetzung: Theorie einer Kunstgattung (1969), based on his Czech publication (1963) rewritten as a manuscript for the German readership in 1967, is now bound to have only a limited audience for linguistic reasons. The difficulty of penetrating the German text becomes evident in some contemporary English writings where the interpretations suggest that German may indeed pose an obstacle, unlike for e.g. Prunč whose interpretation is quite different. This may be compounded by the fact that today there are few earlier-generation scholars who may be familiar with the Czech structuralist underpinnings. Levý is seen as a Russian formalist concerned with 'literariness' in spite of the fact that one never encounters this word in his writings and that Czech structuralism itself represented a straightforward negation of its own domestic formalism. This mistaken belief had to be accounted for as a serious factor in translating Levý into English.

The second reason for translating Levý was the potential relevance and topicality of his theory. After the numerous paradigm shifts in western humanities and Translation Studies Levý is regarded as an early descriptivist be-
Translation Theory be of Use to Translators? (1965) ${ }^{4}$. A tradução alemã de The Art of Translation [Die literarische Übersetzung: Theorie einer Kunstgattung (1969)], baseada na edição tcheca (1963) reescrita na forma de manuscrito para o público alemão em 1967, está fadada, devido a razões linguísticas, a ter apenas um público limitado. A dificuldade de penetrar o texto em alemão torna-se evidente em alguns escritos contemporâneos em inglês cujas interpretações sugerem que a língua alemã pode, de fato, ser um obstáculo - diferentemente do que pensa Prunč ${ }^{5}$, por exemplo, cuja interpretação a esse respeito é inteiramente diferente. Isso pode ser exacerbado pelo fato de que hoje há poucos estudiosos de gerações anteriores familiarizados com as bases do estruturalismo tcheco. Levý é visto como um formalista russo preocupado com a "literariedade", a despeito do fato de que ninguém encontre essa palavra em seus escritos e de que o próprio estruturalismo tcheco seja uma negação direta de seu formalismo doméstico. Essa crença equivocada teve de ser levada em conta como um fator importante na tradução de Levý ao inglês.

A segunda razão para traduzir Levý foi a pertinência e contemporaneidade potenciais de sua teoria. $\mathrm{Na}$ esteira das numerosas mudanças de paradigmas ocorridas nas Humanidades e nos Estudos da Tradução no ocidente, Levý é con-

\footnotetext{
${ }^{4}$ N.T.: Ambos os textos - em suas versões originais e em traduções ao português - fazem parte do dossiê "(Re)descobrindo Levý” publicado neste número e de que faz parte o corrente texto. Conferir pp. 72 e 61, respectivamente.

${ }^{5}$ PRUNČ, Erich. Einführung in die Tranlationswissenschaft, Band 1. ITAT. Graz, Graz Univ 2001.

${ }^{6}$ Por exemplo: GENTZLER, Edwin. Contemporary Translation Studies. London, Routledge, 2001 .
} 
cause he chronologically preceded the polysystem theory; the latter also claims its Russian formalist roots and refers to Jakobson and Levý. Jakobson himself is yet another reason for presuming that Levý was a formalist. Jakobson was originally a Russian formalist and in the 1920s - 1930s, when he lived in Czechoslovakia, a member of the Prague School. In western Translation Studies his well-known writings in English on translation $(1959,1960)$ have been considered representative of the Prague School, and because they pre-dated Levý's articles in English and the German translation of his book, Levý has been regarded as his follower. Czech translation theory dates back to the turn of the $19^{\text {th }}$ and $20^{\text {th }}$ centuries and has been called a functional theory of translation in line with the Czech functional structuralism in which it is grounded. However, in anthologies and accounts of the history of the discipline written in English Levý is not considered a functionalist.

Levý has been stigmatized with Russian formalism while the true theoretical-methodological basis (the semiotic or aesthetic branch of Czech structuralism which subsumed linguistics) has remained largely unknown in our discipline. On the basis of his own extensive empirical research, Levý designed an integral theory and introduced a number of unique con- siderado precursor do descritivis$\mathrm{mo}^{7}$, visto que, cronologicamente, precedeu a teoria dos polissistemas; essa também reclama suas raízes no formalismo russo e faz referência a Jakobson e Levý ${ }^{8}$. O próprio Jakobson é mais outra razão para presumir que Levý era um formalista ${ }^{9}$. Jakobson foi, originalmente, um formalista russo, e quando viveu na Tchecoslováquia, durante os anos 20 e 30, foi membro da escola de Praga. Nos Estudos da Tradução ocidentais, seus bem-conhecidos escritos em inglês sobre tradução $(1959,1960)$ têm sido considerados representativos da escola de Praga, e porque antecedem os artigos de Levý escritos nesse idioma, e à tradução alemã de seu livro, Levý tem sido considerado seu seguidor. A teoria da tradução tcheca remonta ao fim do século XIX e início do XX, e foi chamada de uma 'teoria funcional da tradução', em concordância com o estruturalismo funcional tcheco no qual se baseia. Entretanto, em antologias e narrativas da história da disciplina escritos em inglês, Levý não é considerado um funcionalista.

Levý tem sido estigmatizado com o selo do formalismo russo ao mesmo tempo em que suas verdadeiras bases teórico-metodológicas (o ramo semiótico ou estético do estruturalismo tcheco, que incluía a linguística) têm permanecido, em grande medida, desconhecidas em nossa disciplina. Com base em sua própria e ampla pesquisa empírica, Levý formulou uma teoria comple-

\footnotetext{
${ }^{7}$ Por exemplo: PYM, Anthony. Exploring Translation Theories. London: Routledge, 2010; TYMOCZKO, Maria. Enlarging Translation, Empowering Translators. Manchester, St. Jerome 2007.

${ }^{8}$ Por exemplo: EVEN-ZOHAR, Itamar. "Polysytem studies". In: Poetics Today, 11.1, 1990.

${ }^{9}$ GENTZLER, op. cit.
} 
cepts.

\section{Assumptions and memes}

Perhaps the most recent, summarized image of Levý may be found in Tymoczko:

\begin{abstract}
Other important early contributions to descriptive translation studies were made by the Czech School, including Anton Popovič and Jiří Levý. These writers forged a connection between descriptive studies and Russian formalism, stressing formal aspects of translated texts and translator choice. They also developed the concept of Shift as an alternative to prescriptive language for evaluating translations. Most important for the full emergence of descriptive studies is the work of the Israeli scholars [...] thus setting translation on much broader cultural contexts than had been done earlier.
\end{abstract}

While the readers of Levy's book will easily correct this image by themselves, their potential discouragement comes with Gentzler's where one learns that Prague structuralism was Russian formalism, that Levý unlike Chomsky and Nida focused on form and thus that the focus of the Czech (and Slovak) translation theory was the transference of the surface form, i.e. literariness. In fact, Levý never used this term as he held to the Czech structuralist thesis that form and content cannot be separated as they both make up ta e apresentou diversos conceitos singulares.

\section{Pressuposições e memes}

Talvez a imagem mais recente e resumida de Levý seja aquela encontrada em Tymoczko ${ }^{10}$ :

Outras importantes contribuições iniciais para os estudos descritivos da tradução foram feitas pela escola tcheca, em que se inclui as de Anton Popovič e Jiří Levý. Esses escritores forjaram uma conexão entre os estudos descritivos e o formalismo russo, acentuando os aspectos formais dos textos traduzidos e as escolhas dos tradutores. Também desenvolveram o conceito de shift como uma alternativa à linguagem prescritiva utilizada na avaliação de traduções. Mais importante para a completa emergência dos estudos descritivos foi o trabalho dos acadêmicos israelenses [...] assentando a tradução, desse modo, em contextos culturais muito mais amplos do que havia sido feito anteriormente. ${ }^{11}$

Considerando que os leitores do livro de Levý corrigirão facilmente tal imagem por si próprios, possivelmente sentirão desalento com o livro de Gentzler ${ }^{12}$, em que se é informado que o estruturalismo de Praga era o formalismo russo, que Levý, diferentemente de Chomsky e de Nida, enfocava a forma, e que, portanto, o foco da teoria da tradução tcheca (e eslovaca) era a transferência da forma em sua superfície, ou seja, da 'literariedade'. Em verdade, Levý nunca usou esse termo, pois abraçava a tese estruturalista tcheca de

\footnotetext{
${ }^{10}$ TYMOCZKO, op. cit., 39-40.

${ }^{11}$ N.T.: Todas as citações de outros textos fornecidas por Jettmarová foram traduzidas por nós, não tendo sido pesquisadas potenciais traduções ao português dos textos citados.

${ }^{12}$ GENTZLER, op. cit. $81 \mathrm{n}$.
} 
the semantic structure of the work of art (including its translation). He pointed out the role of the reader, thus stressing the interrelationship between semantics and pragmatics in phenomenological, sociological and ideological terms. There are other aspects that make Czech functional structuralism quite different from Russian formalism and from western theories of translation. This is why it may be difficult to integrate Levý into the picture of mainstream theories. Gentzler, probably in search of some links to major cultures, attaches Levý to both Russian and American cultures, suggesting that one of the reasons why Levy's Art of Translation translated into German (1969) was so instrumental was that:

[...] it took the tenets of Russian Formalism, applied them to the subject of translation, and showed how Formalist structural laws were located in history and interact with at least two literary traditions simultaneously [...] Levý's Formalist roots are revealed by specific linguistic methodology that characterizes his project. Levý began with the linguistic distinctions of translation that his colleague Roman Jakobson [...] laid out in On Linguistic Aspects of Translation (1959) [...] Levý also incorporated the interpretative aspect into his translation theory basing such deduction upon Willard Quine's hypothesis $[\ldots]$

In fact, Jakobson and Quine are only mentioned in Levý's introductory chapters on the then state-of-the-art in the discipline. que forma e conteúdo não podem ser separados, uma vez que ambos compõem a estrutura semântica da obra de arte (incluindo sua tradução). Destacou o papel do leitor, acentuando, desse modo, a interrelação entre a semântica e a pragmática em termos fenomenológicos, sociológicos e ideológicos. Há outros aspectos que fazem do estruturalismo funcional tcheco muito diferente do formalismo russo e das teorias ocidentais da tradução. É por isso que talvez seja difícil integrar Levý ao quadro das teorias dominantes. Gentzler ${ }^{13}$, provavelmente em busca de conexões com culturas de vulto, associa Levý tanto à cultura russa como à americana, sugerindo que uma das razões pelas quais seu texto em alemão - Die literarische Übersetzung: Theorie einer Kunstgattung (1969) - tenha sido tão instrumental foi que:

[...] tomou certos princípios do formalismo russo, aplicou-os ao tema da tradução, e mostrou como as leis estruturais dos formalistas estavam situadas na história e interagem com ao menos duas tradições literárias simultaneamente [...] As raízes formalistas de Levý são reveladas pela metodologia linguística específica que caracteriza seu projeto. Levý partiu das distinções linguísticas da tradução que seu colega Roman Jakobson [...] traçou em On Linguistic Aspects of Translation (1959). [...] Levý também incorporou o aspecto interpretativo em sua teoria da tradução, baseando tal dedução na hipótese de Quine [...]

Em realidade, Jakobson e Quine são mencionados somente nos capítulos introdutórios (da obra de Levý) a respeito do então

\footnotetext{
${ }^{13}$ GENTZLER, op. cit, 82
} 
Levý's theory and method are different, his conception of meaning is based on the Czech reception theory drawing on phenomenology (Husserl, Ingarden), dialectic (Hegel), sociology (Durkheim,Weber), aesthetics (esp. Kant and Hegel). This is why Levý uses the term ideo-aesthetic function of translation suggesting that a work of art has two communicative aspects constituting its whole - the ideological and aesthetic meaning. However, in poetry translation the semantics (sociosemiosis) of form acquires a prominent role, and poetry was Levý's specialism where he also drew on the early Jakobson, but drawing on historical research, comparative poetology and the Czech functional substitution theory he derived his own conception presented in Part II of the book. In other words, whenever Levý treats form the treatment is not formalistic, whenever he speaks of language he sees it as linguistic material that (to a degree) preconditions the expression of thought, but this is only one aspect of many that underlie translation. On closing his chapter on Czech and Slovak theories Gentzler notes: estado da arte da disciplina. A teoria e o método de Levý são distintos; sua concepção de significado é baseada na teoria tcheca da recepção que se serve da fenomenologia (Husserl, Ingarden), da dialética (Hegel), da sociologia (Durkheim, Weber) e da estética (especialmente Kant e Hegel). É por isso que Levý emprega o termo 'função ideo-estética' da tradução a sugerir que a obra de arte possui dois aspectos comunicativos que constituem o seu todo - os significados ideológico e estético. No entanto, na tradução de poesia, a semântica (sociosemiose) da forma adquire um papel proeminente, e poesia era a especialidade de Levý, para cuja análise também se serviu do Jakobson dos primeiros trabalhos; mas ao se servir da pesquisa histórica, da poetologia comparativa e da teoria tcheca da substituição funcional, derivou sua própria concepção (sobre a tradução de poesia) ${ }^{14}$, apresentada na segunda parte do livro. Em outras palavras, sempre que Levý trata da forma, o tratamento não é formalista, sempre que fala de linguagem, vê-a como material linguístico que (até certo ponto) precondiciona a expressão do pensamento - mas esse é apenas um aspecto de muitos que subjazem a tradução. Ao encerrar seu capítulo sobre as teorias tchecas e eslovacas, Gentzler ${ }^{15}$ observa:
The demand to preserve literariness determines the preferred methodology [...]. Russian Formalism defines what has to be valued in a text - aspects such as form, self-referentiality, and technical juxtaposition - and evaluates
A demanda pela preservação da literariedade determina a metodologia preferida [...]. $\mathrm{O}$ formalismo russo define o que deve ser valorizado em um texto - aspectos tais como a forma, a autoreferencialidade e a justaposição

\footnotetext{
${ }^{14}$ N.T.: O entre-parênteses foi uma inserção dos tradutores.

${ }^{15}$ GENTZLER, op. cit, 89-90
} 
translations on the capacity of the target text to transfer those formal characteristics. Yet, different aesthetic approaches as well as different historical moments and cultures may value other aspects of a text. In many ways the translation theory deriving from Russian Formalism reflects precisely those devices - 'defamiliarization' devices for example - that are characteristic of the prevailing artistic norms and interpretative theories of a particular time and place, i.e. modern European society.

This is a historical truth, but the specifics of Czech structuralist theory, method and its origination have escaped attention: in the same period the Czech translation method and theory represented the Russian opposite as it was based on different social realities and theoretical-methodological premises. In collapsing the Russian formalist translation method with Levý's theory Gentzler adds further misunderstandings:

Translation studies scholars avoided theorizing about the relation of form and content [...] Despite claims to the contrary the literary text quickly gets divorced from other socio-political factors. Words cease to refer to real life [...] Art thus becomes autonomous as perception of a work's literariness is tied directly to an awareness of form. It is this quality of calling attention to itself that the theory values and asks to be translated [...] There is a hermetic, selfreferential quality in literary texts which Formalists perceive, value, and recommend be perpetuated. Because Levý and others tended toward the prescriptive, questions técnica - e avalia as traduções conforme a capacidade do texto alvo de trasldarar tais características formais. Contudo, abordagens estéticas distintas, assim como distintas culturas e momentos históricos, podem valorizar outros aspectos de um texto. A teoria da tradução derivada do formalismo russo reflete, de muitas maneiras, precisamente aqueles expedientes - de "desfamiliarização", por exemplo -característicos das normas artísticas dominantes e das teorias interpretativas de uma dada época e lugar, isto é, da sociedade europeia moderna.

Isso é uma verdade histórica, mas as especificidades da teoria estruturalista tcheca, de seu método e de sua origem, escaparam à atenção: no mesmo período, o método e a teoria de tradução tchecos representavam o oposto dos russos, pois estavam baseados em diferentes realidades sociais e premissas teórico-metodológicas ${ }^{16}$. Ao fundir o método de tradução formalista russo com a teoria de Levý, Gentzler $^{17}$ acrescenta mais malentendidos:

Os estudiosos da tradução evitaram teorizar sobre a relação entre forma e conteúdo [...]. Apesar de alegações em contrário, o texto literário é rapidamente divorciado de outros fatores sociopolíticos. As palavras deixam de se referir à vida real [...]. A arte torna-se, assim, autônoma, pois a percepção da literariedade de uma obra é vinculada diretamente a uma consciência da forma. É essa qualidade de chamar a atenção para si própria que a teoria valoriza e pede que seja traduzida [...] Há uma qualidade hermética e auto-referencial nos textos literários que os formalistas percebem, valorizam e recomendam que seja perpetuada. Porque Levý e ou-

\footnotetext{
${ }^{16}$ LEVÝ, Jiří. České theorie překladu. Praha, Ivo Železný 1996, 186-232

${ }^{17}$ GENTZLER, op cit., 89-90.
} 
remain regarding the evaluative horizon.

The opposite is true as the Czech method neither divorces content from form nor structure from its socio-political context, and even if art becomes established as an autonomous system, in the Czech theory it is never treated in a vacuum as it is constantly subject to heteronomous influences, esp. those of human agency. The theory and methodology of Prague aesthetics serving as the launch pad of Levý's work were quite specific already in its Classical Period. In 1940 Mukařovský stated:

Structural aesthetics at this stage of its development is a specific phenomenon of Czech scholarship; although partially similar phenomena may be found in other countries, none of them have methodological foundations elaborated with such consistency; moreover, the issues of artistic structure have been uniquely conceived as the issues of sign and meaning.

It was also the functional focus that made this structuralism specific because function represents a vector between the object and its agentive subject (user) via norm and value. This particular difference from the Russian formal literariness may become obvious also from the following Levý's specification encompassing style, composition and theme: tros tinham uma propensão pela prescrição, questões relativas ao horizonte da avaliação permanecem.

O contrário disso é verdadeiro, pois o método tcheco não divorcia o conteúdo da forma, nem a estrutura de seu contexto sóciopolítico, e mesmo que se venha aestabelecer a arte como um sistema autônomo, na teoria tcheca ela nunca é tratada como se estivesse situada num vácuo, dado que está constantemente sujeita a influências heterônomas, especialmente àquelas da atividade humana. A teoria e a metodologia da estética de Praga que serviram de plataforma de lançamento da obra de Levý já eram bastante específicas em seu período clássico. Em 1940, afirmara Mukařovský:

A estética estrutural, no atual estágio de seu desenvolvimento, é um fenômeno específico dos estudos acadêmicos tchecos; apesar de fenômenos parcialmente semelhantes poderem ser encontrados em outros países, nenhum deles possui fundamentações metodológicas elaboradas com tamanha consistência; ademais, as questões referentes à estrutura artística foram concebidas de forma singular enquanto questões de signo e de significado. ${ }^{18}$

Foi o foco funcional que também tornou esse estruturalismo específico, visto que o conceito de 'função' representa um vetor entre o objeto e seu sujeito agentivo (o usuário) através dos conceitos de 'norma' e 'valor'. Essa diferença particular em relação à 'literariedade' do formalismo russo também pode tornar-se óbvia a partir da seguinte especificação de

\footnotetext{
${ }^{18}$ MUKAŘOVSKÝ, Jan. Studie I. Brno, Host 2007, 21-22.
} 
The aesthetic norm is a strategy leading to a whole raft of instructions for the selection of individual stylistic, compositional and thematic solutions from the set of possible alternatives permitted by the code. In our terminology, therefore, the code is a system of definition instructions for individual paradigms and the aesthetic norm is a set of instructions for making selections within the paradigms. The task will now be to begin work on the analysis of both these systems. (emphasis ZJ)

It was Vilém Mathesius (1913, in Levý 1996: 211), founder and prominent leader of the Prague Linguistic Circle, who proposed the substitution theory in translation as part of the Prague functionalist approach, suggesting a functional substitution of important features to preserve their semantics and the artistic impact of the whole - a theory and practice that go against the grain of Russian formalism. Another example relates to the Russian-formalist and polysystemic vacuums devoid of people when Mukařovský (2007: 506507) in his preface to Shklovsky's translation of Theory of Prose in 1936 points out the different Czech structuralist position:
Levý, que abrange estilo, composição e tema:
A 'norma estética' é uma estraté- gia que conduz a toda uma série de instruções para a seleção de solu- ções estilísticas, composicionais e temáticas individuais a partir do conjunto de alternativas permitidas pelo código. Em nossa terminolo- gia, portanto, o código é um siste- ma de instruções definitórias para paradigmas individuais, e a norma estética é um conjunto de instru- ções para a feitura de escolhas den- tro dos paradigmas. ${ }^{19}$ A tarefa ago- ra será iniciar um trabalho de aná- lise desses dois sistemas. ${ }^{20}$ (entre- aspas da autora)

Foi Vilém Mathesius (1913, in: Levý 1996: 211), fundador e ilustre líder do Círculo Linguístico de Praga, que propôs a 'teoria da substituição' (referente à tradução) como parte da abordagem funcionalista de Praga, sugerindo a substituição funcional das características importantes de um texto a fim de preservar sua semântica e o impacto artístico do todo - teoria e prática que se opõem à índole do formalismo russo. Um outro exemplo refere-se ao vácuo de gente característico do formalismo russo e da teoria dos polissistemas, quando Mukařovský ${ }^{21}$ (2007: 506507), em seu prefácio à tradução de Shklovsky de Theory of Prose (1936), destaca a posição distinta do estruturalismo tcheco:

\footnotetext{
${ }^{19}$ N.T.: Os conceitos de "instrução", "instrução definitória" e "paradigma" que aparecem na citação encontram-se definidos por Levý no texto "A Tradução como um Processo de Tomada de Decisão [Translation as a Decision Process]", publicado bilingualmente nesta edição de Scientia Traductionis - conferir pp. 75 e 76.

${ }^{20}$ LEVÝ, Jiří. Bude literární věda exaktní vědou? Praha: Čs. Spisovatel 1971; in: KRÁLOVÁ, Jana; JETTMAROVÁ, Zuzana (et al). Tradition versus Modernity. From the Classic Period of the Prague School to Translation Studies at the Beginning of the $21^{\text {st }}$ Century. Prague, Charles University 2008, 69.

${ }^{21}$ MUKAŘOVSKÝ, op. cit., 506-507.
} 
The difference between the positions of current structuralism and the quoted formalist thesis may be put this way: the "technique of weaving" is the focus of interest today; however, it is obvious that one must not avoid considering the "situation on the world cotton market", because the development of weaving, even nonmetaphorically, depends not only on the development of weaving technique (i.e. the intrinsic law of the evolving structure), but also on the needs of the market, on supply and demand; mutatis mutandis the same applies to literature. This opens new vistas in the study of the history of literature: it can consider both the continuous evolution of poetry's structure based on constant re-grouping of elements, and external influences [...] univocally shaping each of its stages. Every literary fact thus appears as a product of two forces: the intrinsic dynamics of the structure and external intervention. The fault of traditional literary historical studies was that they only accounted for external interventions and so deprived literature of its autonomous evolution; the one-sided view of formalism, on the other hand, situated literary events in a vacuum [...] I tried to suggest that the field of literary sociology is fairly accessible to structuralism [...]

Structuralism [...] is neither limited to the analysis of form nor in contradiction with the sociological study of literature [...] but it insists that any scientific inquiry shall not consider its material a static and piecemeal chaos of phenomena, but that it shall conceive of every phenomenon as both a result and a source of dynamic impulses, and of a whole as a complex interplay of forces.

While the Czech sociosemiotic conception interrelated any
As diferenças entre as posições do estruturalismo atual e as citadas teses formalistas podem ser colocadas da seguinte maneira: a "técnica da tecelagem" é hoje o foco de interesse; no entanto, é óbvio que não se deve deixar de considerar a "situação do mercado mundial de algodão", porque o desenvolvimento da tecelagem, mesmo de um ponto de vista não metafórico, depende não apenas do desenvolvimento de sua técnica (isto é, da lei intrínseca à estrutura evolutiva), mas também das necessidades do mercado, da oferta e da procura; mutatis mutandis, o mesmo se aplica à literatura. Isso abre novas perspectivas para o estudo da história da literatura: ela pode considerar tanto a evolução contínua da estrutura da poesia, baseada num constante reagrupar de elementos, e as influências externas [...] que modelam de forma unívoca cada um de seus estágios. Todo fato literário, portanto, revela-se como um produto de duas forças: das dinâmicas intrínsecas da estrutura e da intervenção externa. A falha dos estudos histórico-literários tradicionais foi que eles apenas levaram em conta as intervenções externas e, assim, privaram a literatura de sua evolução autônoma; a visão unilateral do formalismo, por outro lado, situou os eventos literários num vácuo [...]. Tentei sugerir que o campo da sociologia literária é favoravelmente acessível ao estruturalismo [...].

O estruturalismo [...] não se limita à análise da forma, nem está em contradição com o estudo sociológico da literatura [...], mas insiste que toda investigação científica não deve considerar seu material um caos de fenômenos estáticos e fragmentados, mas sim conceber cada fenômeno tanto como um resultado quanto como uma fonte de impulsos dinâmicos, e o todo como uma complexa interação de forças.

Ao passo que a concepção sóciosemiótica tcheca inter- 
potential agents involved, it also developed a functional stylistics for all discourse types. Literary poetics was then incorporated in this discipline. Czech structuralists also distanced themselves from western (neo)positivism and its methodology. Levý outlines specific requirements challenging even the Czech methodology and aspiring to tackle the level of explanation:

Whereas the byword of positivism was 'savoir pour prévoir', the programme of the anti-positivist scientific phase, in which we find ourselves today, may be formulated as 'savoir pour construire'. Structuralist tendencies in scientific disciplines investigating complex phenomena had one common thesis: they rejected positivist causality, replacing it with the concept of function, i.e. they do not attempt to discover the causes of phenomena, but to locate them in a higher entity $[\ldots]$. The functional approach is undoubtedly more appropriate for the analysis of systems, for the simple reason that it leads to the investigation of their internal structure, not merely their external relationships (their environment) $[\ldots]$.

The functional approach in classical structuralism suffered from this drawback of a lack of testability in practice; it was not often possible to verify that the specification of the function of an element of the whole accurately represented the relationships existing in the observed phenomenon. [...] Thus positivism formulated genetic hypotheses and attempted to verify them, while the purpose of structuralism is to formulate and verify generative hypotheses. relacionava quaisquer potenciais agentes em jogo, também desenvolvia uma estilística funcional para todos os tipos de discurso. A poética literária foi então incorporada a essa disciplina. Os estruturalistas tchecos também se distanciaram do (neo)positivismo ocidental e de sua metodologia. Levý $^{22}$ esboça alguns requisitos específicos que desafiam até mesmo a metodologia tcheca e almejam atacar o nível da explicação:

Ao passo que a máxima do positivismo era "savoir pour prévoir" (saber para prever), o programa da fase científica anti-positivista em que nos encontramos hoje pode ser formulado como "savoir pour construire" (saber para construir). As tendências estruturalistas nas disciplinas científicas que investigavam fenômenos complexos sustentavam uma mesma tese: rejeitavam a causalidade positivista, substituindo-a pelo conceito de "função"; isto é, elas não buscam descobrir as causas dos fenômenos, mas situá-los numa entidade conceitual de nível superior [...] A abordagem funcional certamente é mais apropriada para a análise de sistemas pela simples razão de que conduz à investigação da estrutura interna desses, e não meramente de suas relações externas (seu meio) $[\ldots]$.

A abordagem funcional no estruturalismo clássico sofreu deste empecilho que é a impossibilidade de ser testada na prática; frequentemente não era possível verificar se a especificação da função de um elemento do todo representava de forma precisa as relações existentes no fenômeno observado. [...] Assim, o positivismo formulava hipóteses 'genéticas' e buscava verificá-las, enquanto o propósito do estruturalismo é o de formular e verificar hipóteses 'generativas'.

\footnotetext{
${ }^{22}$ LEVÝ op.cit., in KRÁLOVÁ, JETTMAROVÁ, op. cit. 70-71.
} 
Czech structuralists are not prescriptivists. However, any discipline concerned with art has an axiological branch involving normativity as the pivotal role on the axiological level is attributed to the receiver and his value system. Before Levý it was Mukařovský who proposed the socio-semiotic concept of norm as a pillar of theory and methodology:

\begin{abstract}
One may speak of a genuine norm only when there are generally accepted goals in respect of which a value is upheld independently of an individual's will and decision making; in other words when the norm exists in what is called collective awareness [...] Although a norm tends to be binding [...] not only may it be violated but, conceivably - as is quite commonplace - two or more competing norms may coexist and be applied to the same specific cases sharing the same value on the scales.
\end{abstract}

On the other hand, $\mathrm{Mu}-$ kařovský and Levý also stressed individual agency in the production and reception processes; for them individual deviations from the norm are inherent and necessary part of discourse, especially in art. Therefore both the collective (intersubjective) and the individual (subjective) are present in the communication process (act). This view may explain why Czech structuralism managed to avoid formalist problems, such as norms and systems existing in a vacuum, or cultural systems devoid of agents. In Czech structuralism not even autonomous systems like literature would have human agents
Os estruturalistas tchecos não são prescritivistas. No entanto, toda disciplina relacionada com a arte tem um ramo axiológico que envolve a normatividade, dado que no nível axiológico o papel principal é atribuído ao receptor e ao seu sistema de valores. Antes de Levý, Mukařovský propôs o conceito sócio-semiótico de 'norma' enquanto pilar da teoria e da metodologia:

Pode-se falar de uma norma genuína apenas quando existirem metas geralmente aceitas com respeito às quais um valor é sustentado independentemente da vontade e da tomada de decisão de um indivíduo; em outras palavras, quando a norma existir naquilo que se chama de consciência coletiva [...]. Apesar da tendência de uma norma ser compulsória [...] não somente pode ser violada, mas, em princípio - como é lugar-comum -, duas ou mais normas em competição podem coexistir e ser aplicadas aos mesmos casos específicos que compartilharem o mesmo valor ${ }^{23}$.

Por outro lado, Mukařovský e Levý também enfatizaram o papel da agência individual nos processos de produção e recepção; para eles, desvios individuais da norma são uma parte inerente e necessária do discurso, especialmente na arte. Portanto, tanto o coletivo (o intersubjetivo) como o individual (o subjetivo) estão presentes no processo (no ato) de comunicação. Essa concepção pode explicar por que o estruturalismo tcheco conseguiu evitar os problemas formalistas, como o de normas e sistemas existirem no vácuo, ou de sistemas culturais serem desprovidos de agentes. No estruturalismo tcheco, nem mesmo sis-

\footnotetext{
${ }^{23}$ MUKǍ̌OVSKÝ, Jan. Estetická funkce, norma a hodnota jako sociální fakt,. Praha, Fr. Borový 1936; in: MUKǍ̌OVSKÝ, Jan. Studie z estetiky. Praha, Odeon 1966, 27-28
} 
in the position of mere structural epiphenomena as it is human agency that influences autonomous systems by interfering with them.

Czech translation theory, conceiving the product in a processual way (i.e. translation as an act of communication), operates a theoretical model that links the lower level of communication (as in Skopos theory) with the higher cultural level (as in Polysystem theory). Social value and axiology represent an integral part on three theoretical levels: the level of the lay receiver, the level of criticism and the meta-level of research.

\section{Conceptual constraints and avoidance of disintegration}

Levý's concepts and terminology have turned out to be a 'minefield'. While their incommensurability was basically due to different traditions and conceptualizations, Levý's theory had to be re-presented as an integral structural whole, possibly avoiding generalizations and loss of specific terminology. For example the concepts of noetic compatibility or translativity - while the former was easily calqued, the latter had to be formed by derivation accounting for the fact that Popovič (1976) coined it as translationality. Such concepts were easier to transfer than conceptual overlaps or other lacunae. For example, English does not have a cover term for reproduction arts; or přbásnění means a specific type of poetry temas autônomos como a literatura teriam os agentes humanos na posição de meros epifenômenos ${ }^{24}$ estruturais, uma vez que é a agência humana que influencia os sistemas autônomos ao interferir neles.

A teoria da tradução tcheca, ao conceber o produto de forma processual (isto é, a tradução como um ato de comunicação), opera com um modelo teórico que relaciona o nível mais básico da comunicação (como na teoria do escopo) ao nível cultural mais sofisticado (como na teoria dos polissistemas). Os valores sociais e a axiologia representam uma parte integral de três níveis teóricos: o nível do receptor leigo, o nível da crítica e o meta-nível da pesquisa.

\section{Limitações conceituais: evitando a desintegração}

Os conceitos e a terminologia de Levý acabaram por se tornar um "campo minado". Ainda que a incomensurabilidade desses se deva basicamente a diferentes tradições e conceitualizações, a teoria de Levý tinha de ser reapresentada como um todo estrutural íntegro, possivelmente evitando-se generalizações e a perda de terminologia específica. Exemplos disso são os conceitos de noetic compatibility ["compatibilidade noética"] e translativity ["translatividade"] ainda que se tenha podido decalcar com facilidade o primeiro deles, o outro teve de ser formado por derivação, levando-se em conta o fato de que Popovič (1976) cunharao como translationality ["translacionalidade"]. Tais conceitos foram mais fáceis de trasladar do que

\footnotetext{
${ }^{24}$ N.T.: Comunicamos uma imprecisão ortográfico-vocabular do original, corrigida aqui: trazia "epiphonemes" em vez "epiphenomena", que conduz, essa, à tradução "epifenômenos".
} 
translation based on functional substitution (Nord calls it homological translation, Jakobson creative transposition adding that this is not a translation). There are also terms related to Ingarden's phenomenological reception - although they do exist in English translations of his writings some have not been translated with consistency (e.g. concretization or concretion) and they are mostly unknown in mainstream Translation Studies.

Czech structuralism drew on a variety of disciplines and some of its concepts or terms were more precise than those used in western TS to this day, and perhaps more rigorously integrated in the conceptual network. We all know about the definitional problem of the original and the translation when translation may be indirect, compiled, fragmentary, plagiary or faked. In general, we are not satisfied with the delimitation of the concept of translation. This issue is illustrated by one term which is a key to uncovering the integrity and thoughtful elaboration of Levy's theory.

Although Levý uses predloha in synonymic variation with the original, the work under trans- sobreposições conceituais e outras lacunas. Por exemplo, o inglês não tem um termo geral que abranja as 'artes reprodutivas'; ou um termo para přbásnění, que significa um tipo específico de tradução poética baseada na substituição funcional (Nord a denomina 'tradução homológica'; Jakobson, 'transposição criativa', acrescentando que não se trata de uma tradução) ${ }^{25}$. Há também termos relacionados à recepção fenomenológica de Ingarden em língua inglesa - ainda que esses termos existam em traduções de obras suas ao inglês, alguns não foram traduzidos com consistência (por exemplo, concretization ["concretização"] ou concretion [“concreção"]) e são na maior parte desconhecidos nos Estudos da Tradução.

O estruturalismo tcheco se serviu de uma variedade de disciplinas, e alguns de seus conceitos ou termos eram mais precisos do que aqueles empregados atualmente nos Estudos da Tradução, e talvez mais rigorosamente integrados à rede conceitual a que pertenciam. Todos nós sabemos o problema que é definir original e tradução quando uma tradução pode ser indireta, compilada, fragmentária, plagiária ou falsificada. De modo geral, não nos vemos satisfeitos com a delimitação do conceito de tradução. Essa questão é ilustrada por um termo que se revela chave para descortinar a integridade e a refletida elaboração da teoria de Levý.

Apesar de Levý empregar predloha em variação sinonímica com 'original', 'obra em tradução'

\footnotetext{
${ }^{25}$ N.T.: Corness traduziu o termo por transversification ["transversificação"]; conferir Levý (2011), p.XX.
} 
lation, the source work he always means the same concept - a prototype that served as the model (direct source) for the derived work, in our case for translation. This term has been taken from outside the discipline (esp. cybernetics, theory of modelling, general systems theory) in the 1920s by Czech structuralists. Prototypes, master copies or models from which copies are made exist in all walks of life and are something we live by (hence the integrated concept of $i l$ lusionism). Even any verbal message is a model of its prototype i.e. of the cognitive counterpart residing in the head of the speaker, of its mental representation. Also a translation is a model of a prototype (model); if it is not its complete representation, then it is its sample (extract, fragment). If it has not been derived from the model and is presented as if it were so, then it is a pseudotranslation (a pseudo-ostension as representation of a non-existing model). If it is a translation presented as an original then its derivation is concealed for whatever reason. A prototype itself may not be the original but a translation as is the case of indirect translation, or a series of models may be derived from one prototype producing a serial or multiple translation.

There are several types of relationships that hold between the prototype model and its derived model. The two most relevant are functional and structural relationships. The functional relationship means that the derived model functions for someone as the represen- e 'obra fonte', ele sempre quer referir o mesmo conceito: um protótipo que serviu de modelo (de fonte direta) para o trabalho derivado, em nosso caso para a tradução. Esse termo foi tomado de fora da disciplina (especialmente da cibernética, da teoria da modelação e da teoria geral dos sistemas) pelos estruturalistas tchecos nos anos 20. Protótipos, cópias matriz ou modelos a partir dos quais cópias são feitas existem em todas as áreas da vida e são coisas com as quais convivemos (destarte o conceito integrado de 'ilusionismo'). Mesmo uma mensagem verbal é um modelo de seu protótipo - ou seja, da contraparte cognitiva que reside na cabeça do falante, de sua representação mental. Também a tradução é um modelo de um protótipo (um modelo); se não é sua representação completa, é então sua amostra (extrato, fragmento). Se não tiver sido derivada de um modelo e for apresentada como se o tivesse sido, trata-se pois de uma pseudo-tradução (uma pseudoostensão enquanto representação de um modelo não existente). Se for uma tradução apresentada como se fosse o original, então sua derivação foi ocultada, seja lá por qual motivo. Um protótipo pode não ser o original, mas sim uma tradução, tal como é o caso da tradução indireta; ou uma série de modelos pode ser derivada de um protótipo, resultando numa tradução serial ou múltipla.

Há diversos tipos de relações que se sustentam entre o 'modelo protótipo' e seu 'modelo derivado'. As duas mais relevantes são a funcional e a estrutural. A relação funcional implica que o modelo derivado funcione para alguém como a representação do protótipo 
tation of the prototype which is not available for direct observation. Such presented models are normally taken at face value, without being questioned on their structural relationships with the prototype (unless the model is found to be defective in its function or there is a certain suspicion). This is the communicative basis of illusio or the category of noetic compatibility mentioned above.

Levý suggests we should also inquire into the structural relationships because function is not indicative of the actual structural relationships; therefore besides a functional model we need a structural one too. And we also need a processual model to understand the generation and reception of the model - they are modelling activities too: the first one (the prototype model or the original) is the verbal representation of reality (the protoprototype, we might say, as a cognitive representation in the original author's head), the second one is the mental representation of this verbalized model by the receiver/translator, the third one is the verbal representation of the translator's cognitive model of the prototype, and the fourth one is the mental representation of the translator's verbalized model by the receiver. Therefore the final representation in translation is a model derived in multiple stages from the original and subject to a number of objective, intersubjective and subjective interfering variables called agents or factors.

The structural relationships between the prototype and its type que não está disponível para observação direta. Tais modelos são normalmente tomados em seu valor de face, sem que se questione suas relações estruturais com o protótipo (a não ser que se descubra que o modelo seja defeituoso em sua função, ou exista uma suspeita disso). Essa é a base comunicativa da illusio ["ilusão"] ou da categoria de 'compatibilidade noética' mencionada acima.

Levý $^{26}$ sugere que também deveríamos investigar as relações estruturais, uma vez que a função não é indicativa das verdadeiras relações estruturais; portanto, além de um modelo funcional, necessitamos também de um modelo estrutural. E também de um modelo processual, a fim de compreender a geração e a recepção do modelo - que também são atividades modeladoras: o primeiro (o modelo protótipo ou original) é a representação verbal da realidade (o protoprotótipo, diríamos, enquanto representação cognitiva existente na mente do autor original); o segundo é a representação mental desse modelo verbalizado pelo receptor/tradutor; o terceiro é a representação verbal do modelo cognitivo que o tradutor possui do protótipo; e o quarto é a representação mental do modelo, verbalizado pelo tradutor, por parte do receptor ${ }^{27}$. Portanto, na tradução, a representação final é um modelo derivado em múltiplos estágios a partir do original e sujeito a um número de variáveis interferentes objetivas, intersubjetivas e subjetivas, denominadas 'agentes' ou 'fatores'.

Espera-se que as relações estruturais entre o protótipo e seu ti-

\footnotetext{
${ }^{26}$ LEVÝ, op. cit.

${ }^{27}$ Ibidem, 13,17.
} 
are supposed to respect the dimensions of isomorphism, isofunctionalism and homology, to one degree or another. In translation structural representativeness or similarity depends on numerous factors. But if iso functionalism is upheld (i.e. translation as a representation of its model in terms of its function/s), other structural requirements may be subordinated to it. It does not mean that the translation has the same function(s) as the original when functioning as its substitute, i.e. as its illusionistic representation - it may have different functions. Therefore whenever Levý says that the translation functions as the original he means that it functions as its model (representation) and because he deals with artistic translation he also means that the translation retains its artistic denomination, i.e. the dominant function (and value) of an artistic artefact like its original, in other terms like its source work (with source not necessarily implying a culture different from the receiving one as in polysystem theory). What is representation meant to involve? A functional substitute operating on the social illusio and with its retrospective structural similarity derived from the contemporary translation norm - the double norm comprising the reproduction norm and the aesthetic norm; the proportion of both subnorms also depends on the historical dimension of translativity and its social value. Hence one of the two subnorms may prevail or the translator may seek their equilibrium in case of a zero value. These are intersubjective factors and the translator is a po respeitem as dimensões do isomorfismo, do isofuncionalismo e da homologia, num ou noutro grau. $\mathrm{Na}$ tradução, a similaridade ou representatividade estrutural depende de numerosos fatores. Mas se o isofuncionalismo for mantido (isto é, se a tradução for a representação de seu modelo no que tange a sua função ou funções), outros requisitos estruturais podem ser subordinados a ele. Isso não implica que a tradução tenha a mesma função/ funções do original quando funciona como seu substituto, isto é, como sua representação ilusionista - ela pode ter diferentes funções. ${ }^{28}$ Portanto, toda vez que Levý afirma que a tradução funciona como o original, ele quer dizer que ela funciona como seu modelo (sua representação), e porque ele lida com a tradução artística também quer dizer que a tradução retém sua denominação artística, isto é, a função (e o valor) dominante de um artefato artístico tal como seu original, ou, em outras palavras, tal como sua 'obra fonte' ('fonte' não necessariamente implicando uma cultura diferente daquela da recepção, tal como na teoria dos polissistemas). No que se pretende que a representação resulte? Num substituto funcional que opere com base na ilusão [illusio] social e que tenha sua similaridade estrutural 'retrospectiva' derivada da norma de tradução contemporânea - a norma dupla que inclui a norma reprodutiva e a norma estética; a proporção dessas duas sub-normas também depende da dimensão histórica da translatividade e de seu valor social. Destarte, uma das duas sub-normas pode prevalecer, ou

\footnotetext{
${ }^{28}$ Conferir a distinção entre tradução isofuncional, heterofuncional e homológica em: NORD, Christianne. Translation as a Purposeful Activity. Manchester, St. Jerome 1997.
} 
subjective factor; the result of applying a translation method depends on his individual dispositions and preferences.

However, in terms of its prospective properties, i.e. with a view to the receiver's dispositions and the historical and situational contexts this basic representational function may be carried by different structural properties. Here Levý proposes a tentative list of invariant and variant properties in several genres. When he says that variability and invariability depend on the structure of the texts under translation and not on the intended goal of the translation, we come across yet another important distinction; the Czech conception is based on the already mentioned sociosemiotic triad of norm, function and value. The pragmatic concept of goal or purpose of communication (i.e. teleology) is superimposed: the sender presents the functional substitute of the original to the receiver in a concrete situation in order to achieve something through communication conceived as interaction. The derived artefact is a linguistic and cultural hybrid, relating to two cultures and languages, and preferences on the scales between the domestic and the foreign (i.e. translativity) are again steered by objective, intersubjective and subjective factors involved. As a semiotic sign the source work has two aspects - its material form carries the artistic message or the work of art in a narrow sense, and it is the latter o tradutor pode procurar seu equilíbrio, no caso do valor ser zero. Esses fatores são intersubjetivos e o tradutor é um fator subjetivo; o resultado da aplicação de um método de tradução depende de suas inclinações e preferências individuais.

Entretanto, no que tange as suas propriedades 'prospectivas', isto é, com o olhar voltado para as inclinações do receptor e para os contextos histórico e situacional, essa função representacional básica pode ser transmitida por diferentes propriedades estruturais. Aqui Levý ${ }^{29}$ propõe uma lista tentativa de propriedades variantes e invariantes em diversos gêneros. Quando afirma que a variabilidade e a invariabilidade dependem da estrutura dos textos em tradução, e não da meta pretendida para a tradução, nos deparamos com mais uma importante distinção; a concepção tcheca é baseada na já mencionada tríade sócio-semiótica composta por norma, função e valor. $\mathrm{O}$ conceito pragmático de 'meta' ou 'propósito' da comunicação (isto é, de teleologia) é sobreposto: o emissor apresenta $\mathrm{o}$ substituto funcional do original ao receptor em uma situação concreta, a fim de obter algo, através da comunicação concebida como interação. O artefato derivado é um ‘híbrido' cultural e lingüístico que se relaciona com duas culturas e línguas, e as preferências, na balança entre o doméstico e o estrangeiro (isto é, a translatividade), são uma vez mais dirigidas pelos fatores objetivos, intersubjetivos e subjetivos em jogo. Enquanto signo semiótico, a obra fonte possui dois aspectos - sua forma material

\footnotetext{
${ }^{29}$ LEVÝ, Jiří. Umění překladu. Praha, Panorama 1983, 22-24.
} 
that undergoes translation while the linguistic material is substituted. This structuralist differentiation is important for understanding the distinctions or overlaps between work and text as well as the relationships between form and content.

Czech Classical structuralists avoided rigid and essentialistic definitions as they preferred looser delimitations and explanations. This advantage turned out to be a disadvantage during the translation of Levý's book as the correct understanding and interpretation of concepts rely on the knowledge of a specific background; intertextuality was at work here too, as much that (what) ${ }^{30}$ is explicitly stated by Levý elsewhere is left implicit in the book and footnotes had to be added.

\section{In conclusion}

There is always more to a translation than one can see from the outside as a reader. Translating Levý was a challenge and if the translation was to serve its purpose the retrospective concern was the representation of the original and the prospective concern was the facilitation of correct understanding and interpretation on the part of the international scholarly community. Both aspects involved concerns with the implicit and unknown background, distorted images, terminology issues and efforts to avoid disintegration of the structural network. Numerous debates between the translator and transporta a mensagem artística ou obra de arte, num sentido estrito, e é essa que é traduzida enquanto o material linguístico é substituído. Essa diferenciação estruturalista é importante para entender as distinções ou sobreposições entre 'obra' e 'texto', assim como as relações entre 'forma' e 'conteúdo'.

Os estruturalistas tchecos evitaram definições rígidas e essencialistas porquanto preferiam delimitações e explicações mais frouxas. Essa vantagem acabou por se tornar uma desvantagem durante a tradução do livro de Levý, pois a compreensão e interpretação corretas de seus conceitos dependem do conhecimento de um pano de fundo específico; a intertextualidade também operava aqui, a tal ponto que o que é afirmado explicitamente por Levý noutras partes foi deixado implícito no livro, e notas de rodapé tiveram de ser adicionadas.

\section{À guisa de conclusão}

Sempre há mais coisas numa tradução do que se pode ver de fora como leitor. Traduzir Levý foi um desafio, e para que a tradução cumprisse seu objetivo, a preocupação retrospectiva foi a de representar o original, e a prospectiva a de facilitar a compreensão e a interpretação corretas da obra de Levý por parte da comunidade acadêmica internacional. Ambos os aspectos envolviam preocupações com o pano de fundo implícito e desconhecido, com imagens distorcidas, com questões de terminologia, e esforços para evitar a desintegração da rede estrutural. Numerosos debates entre o tradu-

\footnotetext{
${ }^{30}$ N.T.: Este "what" foi inserido no texto por nós.
} 
editor over interpretation of meaning and choice of words bear silent witness to the process of creating a basically illusionistic translation. Levý's style of writing deserves a brief mention. One may ask if it is Levý's style that is actually presented, because the sources were translations from the unavailable Czech manuscript into German (1969) and from German back into Czech (1983/1996). Patrick Corness, the translator of the English version, was very sensitive to the style and had to compromise between the intricacies of an amazing lightness on the one hand, and the heavy theoretical load on the other.

Levý said about his book that he presented a theory of artistic translation only, but he also presented a general theory of translation, methodological guidelines for research, criticism and a recipe for translators and their trainers. Perhaps with a less pronounced 'vivisection' of the discipline than Holmes' but with more deeds than words. When the book comes out we shall hopefully also preclude numerous rediscovery efforts of literary newcomers on the TS scene. Supposed they read the book first.

Levý (1971: 155-156) said that universalisation (i.e. globalisation) in modern culture is not based on general spiritual values (allgemeine Kulturgut), but on the exchange of spiritual values, on the upsurge of communication be- tor e esta editora sobre a interpretação de significados e escolha de palavras oferecem um testemunho silencioso do processo de criação de uma tradução que é basicamente ilusionista. O estilo de escrita de Levý merece uma breve menção. Pode-se questionar se o estilo de Levý é, de fato, apresentado, visto que as fontes foram traduções do indisponível manuscrito tcheco ao alemão (1969) e do alemão de volta ao tcheco (1983/1996). Patrick Corness, o tradutor da versão em língua inglesa, foi muito sensível ao estilo e teve que encontrar um meio-termo entre minúcias de incrível leveza, por um lado, e uma pesada carga teórica, por outro.

Levý disse sobre seu livro que ofereceu apenas uma teoria da tradução artística, mas também ofereceu uma teoria geral da tradução, diretrizes metodológicas para a pesquisa, crítica, e um receituário para tradutores e seus instrutores. Talvez com uma "vivisseção" menos pronunciada da disciplina do que a feita por Holmes ${ }^{31}$, mas com mais feitos do que palavras. Quando o livro for publicado, com sorte também preveniremos numerosos esforços de redescoberta de recémchegados da literatura ao cenário dos Estudos da Tradução ${ }^{32}$. Desde que leiam o livro primeiro.

Levý afirmou que na cultura moderna a universalização (isto é, a globalização) não se baseia em valores espirituais 'amplamente compartilhados' (allgemeine Kulturgut), mas no 'intercâmbio' de valores espirituais e no rápido au-

\footnotetext{
${ }^{31}$ HOLMES, John. "The Name and Nature of Translation Studies", In: Translated!, 1988 Amsterdam, Rodopi 1988, 67-80.

${ }^{32}$ OURIOU, Susan (ed). Beyond Words: Translating the World. Banff, Alberta: Banff 2010.
} 
tween diverse cultural regions; literary translation is a force contributing to both the diversification of domestic genres and to the establishment and evolution of world literature. In relation to our discipline the desideratum of this translation project has been similar. mento da comunicação entre regiões culturais diversas; ${ }^{33}$ a tradução literária é uma força que contribui tanto para a diversificação dos gêneros domésticos, como para o estabelecimento e a evolução da literatura mundial. Com relação à nossa disciplina, o desideratum deste projeto de tradução foi similar.

\section{Zuzana Jettmarová \\ Zuzana.Jettmarova@ff.cuni.cz Prof. doutora, Universidade Carolina de Praga}

Fonte: "Translating Jiř́ Levý's Art of Translation for an International Readership", in Králová, Jana (ed.), Posibilidades y Límites de la Comunicación Intercultural. Ibero-Americana Pragensia - Supplementum, 27/2011.

Tradução de:

Gustavo Althoff gualthoff@gmail.com Pós-doutorando, Universidade Federal de Santa Catarina

Gustavo Sartin

ghsartin@gmail.com Mestre egresso, Universidade Federal do Rio Grande do Norte

\footnotetext{
${ }^{33}$ LEVÝ, Jiří. Bude literární věda exaktní vědou?. Praha, Čs. Spisovatel 1971, 155-156.
} 